Primljen / Received: 13.1.2017. Ispravljen / Corrected: 31.3.2017.

Prihvaćen / Accepted: 21.4.2017. Dostupno online / Available online: 10.7.2017.

\section{Review of empirical models for estimation of dune field characteristics}

Authors:

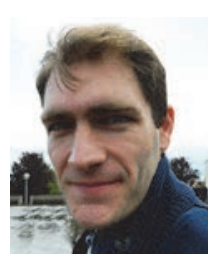

Gordon Gilja, PhD. CE

University of Zagreb

Faculty of Civil Engineering

ggilja@grad.hr

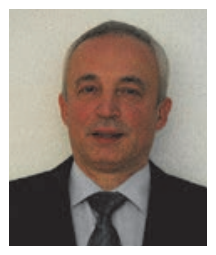

Prof. Neven Kuspilić, PhD. CE

University of Zagreb

Faculty of Civil Engineering

kuspa@grad.hr

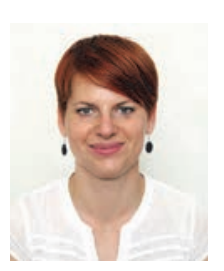

Kristina Potočki, PhD. CE

University of Zagreb

Faculty of Civil Engineering

kpotocki@grad.hr

\section{Gordon Gilja, Neven Kuspilić, Kristina Potočki}

Original scientific paper

\section{Review of empirical models for estimation of dune field characteristics}

The paper presents an overview of the current state-of-the art and an approach to the study of dunes by analysing direct generators of physical processes in river beds. The approach is based on velocity measurements for mobile bed characterised by transport of bed load using the acoustic doppler current profiler (ADCP). The influence of mobile bed velocity on morphodynamic processes has remained unexplored to this day.

Key words:

dunes, bed load sediment, apparent bedload velocity, turbulence, ADCP

Izvorni znanstveni rad

Gordon Gilja, Neven Kuspilić, Kristina Potočki

Analiza primjenjivosti empirijskih modela za opis karakteristika polja dina

U radu je prikazan pregled sadašnjih spoznaja i pristup istraživanju dina proučavanjem neposrednih generatora fizikalnih procesa u koritu. On se temelji na mjerenjima brzine pokretnog dna koja karakterizira kretanje vučenog nanosa pomoću akustičnog strujomjera (ADCP-a). Utjecaj brzine pokretnog dna na morfodinamičke procese do danas je ostao neistražen.

Ključne riječi:

dine, vučeni nanos, brzina pokretnog dna, turbulencija, ADCP

Wissenschaftlicher Originalbeitrag

Gordon Gilja, Neven Kuspilić, Kristina Potočki

\section{Analyse der Anwendbarkeit empirischer Modelle zur Beschreibung der Eigenschaften von Dünenfeldern}

In dieser Arbeit wird eine Übersicht derzeitiger Kenntnisse und Forschungsansätze zur Betrachtung von Dünen hinsichtlich der Generatoren physikalischer Prozesse im Flussbett gegeben. Diese basiert auf Messungen der Geschwindigkeit des Bodens, die Bewegungen mitgezogener Ablagerungen beschreiben, mittels akustischer Strömungsmessgeräte (ADCP). Einflüsse der Geschwindigkeit beweglichen Bodens auf morphodynamische Prozesse bleiben bis heute unerforscht.

Schlüsselwörter:

Dünen, Ablagerungen, Geschwindigkeit beweglichen Bodens, Turbulenz, ADCP 


\section{Introduction}

The alluvial riverbed forms under interaction between the river flow riverbed material and sediment transport. The unique dynamics of turbulent river flow enables transport of huge quantities of bedforming sediment over great distances. Once entrained by the flow, sediment transported downstream is deposited when flow energy decreases to the point that cannot withstand keeping particles in motion. Deposited sediment forms sedimentary bodies in the riverbed (bedforms), thus changing the riverbed morphology. The size and shape of bedforms are a function of hydrodynamic forces that are imposed on the riverbed by the flow, and by properties the riverbed material [1-3]. Various bedforms will develop under different hydraulic conditions, and the bedform changes according to an increase in the Froude's number $(F r)$ from ripples and dunes under subcritical flow regime $(F r<1)$, over plane bed under transitional regime $(F r \sim 1)$, to standing waves and antidunes in supercritical flow regime $(\mathrm{Fr}>1)$. Two types of bedforms are most frequently encountered in the lower courses of rivers: ripples, of relatively small dimensions ( $<0.1 \mathrm{~m}$ in height and $<0.5 \mathrm{~m}$ in length) that don't significantly influence the flow field, and dunes, of relatively large dimensions, that are in interaction with the flow field through the entire water column. Dunes are the most frequent bedforms in sand-bed rivers as they occur in diverse materials, ranging from silt to gravel [4-9]. The presence of dunes in riverbed greatly influences resistance to flow as their dimensions, length and height, are of the same order of magnitude as the flow depth. Additional resistance to flow occurs due to distribution of dynamic pressure along the surface of dunes, which causes local accelerations and decelerations of flow accompanied by increased turbulence through which the energy is dissipated [10]. An increased resistance to flow is especially important for water level calculation using Bernoulli equation where it is expressed as local loss between two sections. An increase in local loss results in greater water levels in upstream sections of the river, which is especially significant during calculation of high flow water levels for design exceedance probability. Bedform related shear stress $\mathrm{t}^{\prime \prime}{ }_{0}$ may exceed by two times the skin-friction shear stress $\mathrm{t}_{0^{\prime}}$ as shown in the following figure (Figure 1).

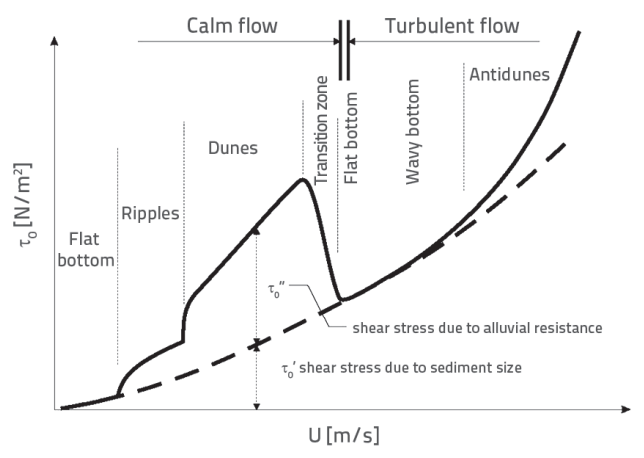

Figure 1. Dependence of resistance to flow expressed via shear stress components $\tau_{0}$ in function of the mean flow velocity $U[11]$

This figure shows bed shear stress as a function of the mean flow velocity, which is related to unit stream power. Total bed shear stress is expressed through the Manning's equation used for describing the losses between two sections in one-dimensional approach to flow modelling.

The dynamics of high flow events initiates development of dunes which consequently influence the flow field characteristics and its sediment transport capacity. Current knowledge about the formation and development of dunes in unsteady flow conditions such as a high flow event is limited, which is mostly due to scaling issues arising from implementation of flume experiments to real scale conditions. Limiting discharge and depth under which is rational to conduct field survey are $Q$ $=500 \mathrm{~m}^{3} / \mathrm{s}$ and $h=3$, respectively. Beyond that, survey cost increases and their reliability decreases with an increase in depth and the spatial extent, which makes the stationarity of measured variables questionable [16]. Measurements under high water flow events are additionally limited by the debris, which carried by flow represents a hazard to equipment and compromises the measurements. Aforementioned limitations have restricted research of dune field characteristics and it has remained a largely unexplored area and a hindrance concerning morphodynamic processes in alluvial beds [12-15].

Flow characteristics over dune fields have mainly been researched by flume experiments on fixed dunes, where the ratio of the flow depth $\left(h=A / B[\mathrm{~m}], A-\right.$ flow area $\left[\mathrm{m}^{2}\right], B-$ top channel width [m]) to particle size $d$ [mm] greatly differs from flows in nature. These relationships are important because of their influence on turbulence which is proportional to the depth of flow, and so the validity of extrapolation of relationships derived in laboratory to conditions in nature and their applicability is highly questionable. Interaction between dunes and their direct generators from the flow field primarily requires detailed knowledge of river hydraulics. An overview of the current state-of-the-art research focusing on the study of dunes and direct generators of physical processes in riverbed is presented in this paper. An overview of current research is given and future research direction is proposed, which should be based on implementation of innovative techniques in the field of river morphodynamics aimed at deepening the knowledge of physical processes in the riverbed.

\section{Relationship between dune geometry and direct generators of their formation}

Dune size is directly influenced by the bedload sediment transport and, indirectly, by various flow parameters such as: discharge, depth, energy slope, stream power, shear stress and sediment properties [13, 17-20]. In river beds formed in medium-sized and coarse sand the total amount of bedload participates in dune migration [4, 21-23]. Unit bedload transport $\mathrm{q}_{\mathrm{b}}$ can be calculated from geometrical properties of dunes and from their migration rate [24]:

$q_{b}=\rho_{\mathrm{s}} \cdot(1-\phi) \mathrm{b} \cdot \mathrm{c} \cdot \eta\left[(\mathrm{kg} / \mathrm{s}) / \mathrm{m}^{\prime}\right]$

where: 
$q_{b}$ - unit bedload transport[kg/s],

$\rho_{s}$ - sediment density $\left[\mathrm{kg} / \mathrm{m}^{3}\right]$,

$\phi$ - porosity of the sand-bed [-],

$c$ - dune migration rate $[\mathrm{m} / \mathrm{s}]$,

$\eta$ - dune height [m],

b - dune shape factor [-] that is determined as follows

$\beta=\frac{A_{D}}{\lambda \cdot \eta}[-]$

where:

$A_{D}$ - longitudinal section area of a dune $\left[\mathrm{m}^{2}\right]$,

$\lambda$ - dune length [m].

Deeper insight into bedload transport mechanisms in rivers would greatly facilitate study of dune morphodynamics. However, bedload measurements in the field are rarely conducted as they require considerable resources. In addition, it is almost impossible to conduct such measurements using traditional methods during high water flow involving considerable depths and velocities, although these events are the ones that move and rearrange large quantities of sediments, causing sudden morphological changes in riverbed. Under conditions that are favourable to sediment transport surveys, simultaneous collection of data about sediment transport, dune field and flow field characteristics is hindered by survey procedure and limitation of equipment. The placing sediment transport survey equipment causes disturbance in the flow field, and so it is impossible to simultaneously gather unbiased data about sediment transport and velocity profile. All these limitations represents obstacles to collection of goodquality and reliable dataset of all flow parameters that influence dune formation, shape and migration rate in natural watercourses. That is why current dune research includes variables that indirectly influence sediment transport and represent the force that is exerted by flow on the riverbed, such as the stream power and shear stress, which include within them flow velocity and energy slope therefore describing characteristics of the flow over dunes [25]. During high flow events an increased stream power caused by increase in energy slope leads to more intense bedload transport that participates in the dune formation. Bartholdy et al. concluded that the change in energy slope influences configuration of the dune field under conditions of an invariable flow depth. This principle was confirmed by Ikeda and Iseya in 1980 based on survey they conducted in the Teshio River in Japan. Ikeda and Iseya attributed the variation of dune field geometry to the change in flow velocity, i.e. to the energy slope, and suggested that these variables be included in analyses of the dune field response to flow field. Guided by this assumption, van Rijn described bedload transport $q_{b}$ with a sufficient accuracy using two dimensionless parameters [18]:

1. particle parameter $d *$ :

$d_{*}=d_{50} \cdot\left[\frac{(s-1) \cdot g}{v^{2}}\right]^{1 / 3}[-]$
2. transport stage parameter $T$ :

$T=\frac{u_{*}^{2}-u_{*}^{2}, g r}{u_{*}^{2}}[-]$

$\mathrm{d}_{50}$ - mean particle diameter [m],

$s \quad$ - specific density, $s=\left(\rho_{s}-\rho\right) / \rho_{s}[-]$,

$\rho$ - water density $\left[\mathrm{kg} / \mathrm{m}^{3}\right]$,

$g$ - gravitational acceleration $\left[\mathrm{m} / \mathrm{s}^{2}\right]$,

$v$ - kinematic viscosity coefficient $\left[\mathrm{m}^{2} / \mathrm{s}\right]$,

$\mathrm{u}_{*}$ - bed-shear velocity related to grains [m/s],

$\mathrm{u}_{*, \mathrm{gr}}$ - critical bed-shear velocity according to Shields [m/s].

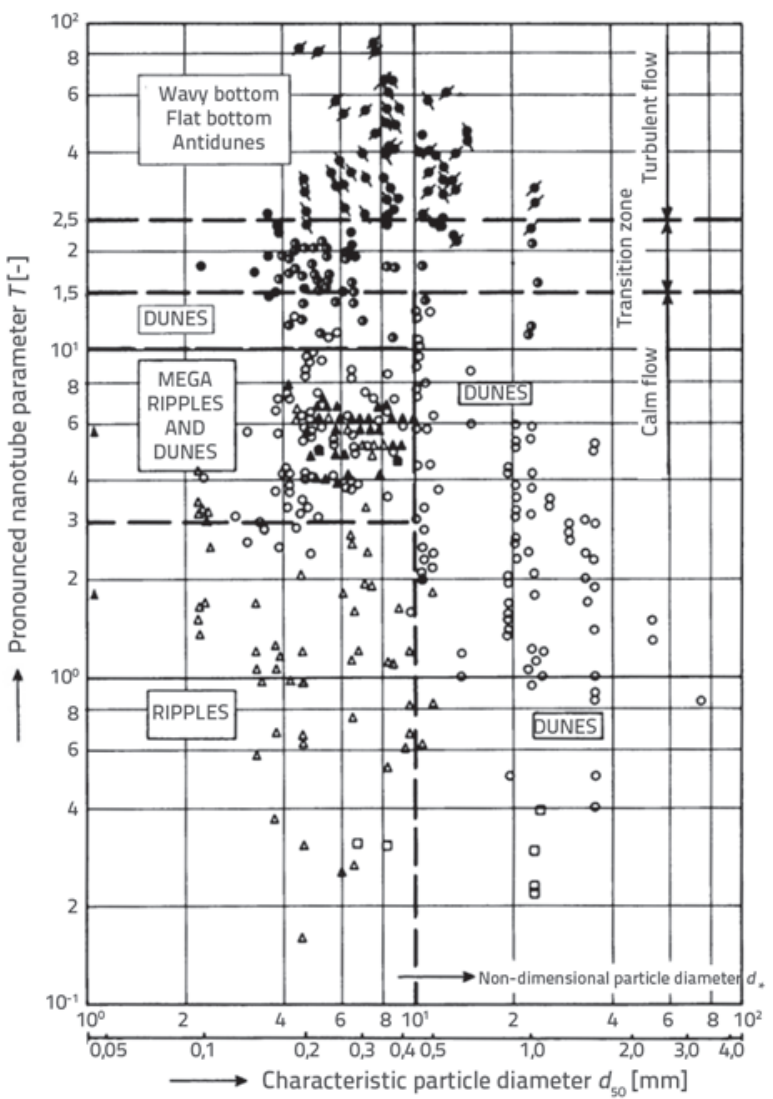

Figure 2. Phase diagram for bedform classification according to van Rijn [18]

Using dimensionless parameters, van Rijn developed a phase diagram for bedform classification. In this diagram, size of sediment material that riverbed is comprised of is represented by the variable $d *$, while characteristics of the flow field are represented by the variable $T$. Van Rijn's phase diagram is considered to be the tool for classification of bedforms in watercourses as it is derived from the combined dataset including a wide range of hydraulic parameters. Van Rijn dependences were derived from laboratory datasets (84 datasets with particles ranging from 190 to $2300 \mu \mathrm{m}$ in diameter) and field datasets (22 datasets with particles ranging from 490 to $3600 \mu \mathrm{m}$ in diameter) gathered from various sources. Similar bedform classifications were proposed 
by other authors (Liu, Garde-Albertson, Engelund-Hansen Simons-Richardson), but are considered to be less reliable as they are conducted exclusively in laboratory or on small rivers [18]. The phase diagram presented below shows the bedform classification as a function of parameters $d_{*}$ and $T$, according to van Rijn:

According to van Rijn, asymmetric dunes with lengths exceeding the mean flow depth $(\lambda>>h)$ are prevailing under conditions of $T \leq 15$. Although it is assumed in the van Rijn analysis that the parameter $d_{*}$ is significant during creation of bedforms, its significance was not visible on the dune datasets. Therefore, only transport stage parameter $T$ is used in the analysis of the dune geometry. The following equation is used for the dune height calculation:

$$
\frac{\eta}{h_{S}}=f\left(\frac{d_{50}}{h_{S}}, T\right)=0,11 \cdot\left(\frac{d_{50}}{h_{S}}\right)^{0,3} \cdot\left(1-e^{-0,5 \cdot T}\right) \cdot(25-T)[-]
$$

where:

$h_{s}$ - average flow depth measured across dune length [m]; and dune steepness $\eta / \lambda$ and dune steepness:

$\frac{\eta}{\lambda}=f\left(\frac{d_{50}}{h}, T\right)=0,15 \cdot\left(\frac{d_{50}}{h}\right)^{0,3} \cdot\left(1-e^{-0,5 \cdot T}\right) \cdot(25-T)[-]$

The combination of these two equations can be used for dune length estimate as a function of the mean flow depth:

$\lambda=7,3 \cdot \mathrm{h}[-]$

which coincides with similar dependence that was theoretically derived by Ali et al. ([26],Table 1).

\section{Interaction of dunes with instantaneous flow field}

Bagnold assumed that during continuous saltation of particles along the riverbed the mean velocity in the flow direction is the velocity at which there is a balance between the mean force acting on a particle due to skin friction and form drag, and the mean longitudinal friction between the particle and the bed. The saltation height is a function of the sediment size $f\left(d_{*}\right)$ and so it will be a function of the flow velocity in the direction of the particle movement. Bagnold equation by which this dependence can be expressed, with $10 \%$ of error, is given as follows [27]:

$\frac{U^{2}}{u_{*}}=9+2,6 \cdot \log d_{*}-8 \cdot \sqrt{\frac{\Theta_{g r}}{\Theta}}[-]$

where:

$U$ - mean flow velocity [m/s]

$\Theta_{\mathrm{gr}}$ - Critical Shields number [-]

$\Theta^{\mathrm{gr}}$ - Shields number determined as [28]:

$$
\Theta=\frac{\tau_{0}}{g \cdot\left(\rho_{S}-\rho\right) \cdot d}[-]
$$

where:

$\tau_{0}$ - shear stress [N/m²]

d - mean diameter sediment particles [m].

Prent and Hickin studied dependence of the dune length and height on the flow velocity and concluded that it is almost linear. Similar conclusions were made by Jackson and Gabel as well as Babakaiff and Hickin. Based on Bagnold's equation, equivalent empirical procedures were also developed for predicting sediment transport over the dune field using the average flow velocity as predictor variable. Empirical relationships derived using such assumptions are unreliable as the space- and time- averaged models are inadequate for describing sediment transport dynamics influenced by near-bed turbulence [25, 2933]. Hydrodynamic forces that initiate sediment transport are resulting from instantaneous flow fluctuation in their vicinity, i.e. they are the result of macroturbulent eddies [34, 35]. Turbulence occurs as instability in the flow caused by shear stress, and shear stress occurs as a spatial variation of flow velocity. Nelson et al. confirmed that vertical eddies created in the process of floe separation and reattachment downstream of the dune crest influence sediment transport by entraining bed particles into the flow $[3,36,37]$. Experimental studies show that impulse is more important than force for incipient motion of sediment particles because it can individually address the influence of the hydrodynamic drag and lift force on a particle, which is especially important when the particle is only partly exposed to flow field. The influence of impulse is highlighted in cases when instantaneous peaks of fluctuating velocity components exceed the time averaged bed-shear velocity and initiate particle movement. The influence of dunes on turbulence structure is significant, which is why relevant research is directed towards development of the theory of evolution of erodible beds under the influence of near-bed turbulence. The bed-shear velocity calculated from the acceleration of the mean flow velocity in the bottom layer is a measure of shear stress caused by the occurrence of dunes, independent from the flow depth. The impulse is applied as criterion for calculation of hydrodynamic forces acting on sediment particles in the models based on the discrete element method, where movement of each particle is in accordance with the local flow field around this particle. It is assumed that this criterion will be used in the future as an equivalent to the Shields curve [38]. The use of such models is currently considered to be impracticable due to complex interaction with the flow field which requires considerable computational resources, and is not rational from the standpoint of applicability and calculation speed. It is in fact the antipodal approach to averaging parameters thorough the water column. As an intermediate step between the above mentioned extremes for describing the flow field, this paper suggests approach that is equally efficient and reliable, based on flow modelling using 
averaged values and modelling the particle movement process at the level of individual particles by direct measurement of the apparent bedload velocity. The advancement of such research procedures is made possible by the use of Acoustic Doppler Current Profilers (ADCP) that measure the flow field near the bed without disturbing the sediment transport regime.

\section{Influence of flow parameters on dune formation}

Research conducted up to date have confirmed the relationship between the flow depth and dune geometry, i.e. the flow depth has been identified as a limiting factor for dune development. When taking into consideration the simplicity of flow depth measurement, it is clear why this parameter has most frequently been selected as predictor variable for the analysis of reaction of the dune field to the flow field over it. Many researchers, including van Rijn, Julien and Klaassen, Allen, Lin, Yalin, etc., have used their own data to generate simple empirical principles for determining the dune geometry as a function of flow depth. Equations presented by various authors to estimate dune dimensions are shown in Table 1 below [13, 18, 25, 27, 39-42].

Table 1. Dependence of dune length $\lambda[\mathrm{m}]$ and dune height $\eta[\mathrm{m}]$ on flow depth $h[\mathrm{~m}]$ according to developed empirical models

\begin{tabular}{|c|c|c|}
\hline Model & Dune length $\lambda$ [m] & Dune height $\eta$ [m] \\
\hline Yalin (1964) & $5 \cdot h$ & $0.167 \cdot h$ \\
\hline Neill (1969) & $1.3-7 \cdot h$ & $0.14-0.6 \cdot h$ \\
\hline Allen (1970) & $1.16 \cdot h^{1.55}$ & $0.086 \cdot h^{1.19}$ \\
\hline Jackson (1976) & $4-9 \cdot h$ & $0.2 \cdot h$ \\
\hline Yalin (1977) & $2 \cdot \pi \cdot h$ & / \\
\hline Fredsøe (1982) & / & $0.285 \cdot h$ \\
\hline van Rijn (1984) & $7.3 \cdot h$ & / \\
\hline Prent (1998) & $1.29-4.70 \cdot h$ & $0.05-0.24 \cdot h$ \\
\hline Gabel (1993) & $6.42 \cdot h-0.27$ & $0.36 \cdot h-0.026$ \\
\hline Garde - Isaac (1993) & $4.737 \cdot h$ & / \\
\hline Julien - Klaasen (1995) & $2,5 \cdot \eta \cdot\left(\frac{h}{d_{50}}\right)^{0,3}$ & $2,5 \cdot h \cdot\left(\frac{d_{50}}{h}\right)^{0,3}$ \\
\hline Mohrig - Smith (1996) & / & $0.247 \cdot h+0.0156$ \\
\hline Prent - Hickin (2001a) & $2.523 \cdot h-0.656$ & $0.215 \cdot h-0.163$ \\
\hline Prent - Hickin (2001b) & $2.853 \cdot h-1.238$ & $0.178 \cdot h-0.091$ \\
\hline Saad i dr. (2001) & / & $0.1 \cdot h$ \\
\hline Kassem (2003) & $99 \cdot h^{1.45}$ & $0.427 \cdot h^{0.57}$ \\
\hline Ali i dr. (2010a) & $7.636 \cdot h$ & $0.19 \cdot h$ \\
\hline Ali i dr. (2010b) & $2.4 \cdot h$ & $0.0902 \cdot h$ \\
\hline
\end{tabular}

Empirical relationships from the models given in table (Table 1) are compared to available field survey data available from literature. The comparison was made for empirical relationship between the flow depth and dune geometry: dependence of dune height on flow depth $\eta=f(h)$, and dependence of dune length on flow depth $\lambda=f(h)$. Relevant data pairs are overtaken from the following models: Gabel's model [30], model presented by Ali et al. [26], and the Prent-Hickin model [25]. Gabel performed several field survey campaigns at the Calamus River (Nebraska, USA) in the period from 1984 to 1986 . The discharge varied from $0.82 \mathrm{~m}^{3} / \mathrm{s}$ to $2.03 \mathrm{~m}^{3} / \mathrm{s}$. Dune geometry observed during these campaigns was the following: average length ranging from $2.0 \mathrm{~m}$ to $4.2 \mathrm{~m}$, average height ranging from $0.1 \mathrm{~m}$ to $0.2 \mathrm{~m}$ and dune steepness $\eta / \lambda$ varied from 0.050 to 0.065 . Ali et al. measured dune field characteristics at the Nile River in two periods: in August 2008 and November 2009. The flow velocity varied for the first and second period from $0.31 \mathrm{~m} / \mathrm{s}$ to $0.61 \mathrm{~m} / \mathrm{s}$ and from $0.62 \mathrm{~m} / \mathrm{s}$ to $0.80 \mathrm{~m} / \mathrm{s}$, respectively. The flow depth for the first and second period varied from $3.5 \mathrm{~m}$ to $7.0 \mathrm{~m}$ and from $2.5 \mathrm{~m}$ to $7.5 \mathrm{~m}$, respectively. The average length of dunes ranged from 3 $\mathrm{m}$ to $70 \mathrm{~m}$ in the first period and from $3 \mathrm{~m}$ to $50 \mathrm{~m}$ in the second period. The average height of dunes varied from $0.1 \mathrm{~m}$ to $1.8 \mathrm{~m}$ in the first period and from $0.1 \mathrm{~m}$ to $1.5 \mathrm{~m}$ in the second period. Prent and Hickin observed dune field characteristics at two dune fields in the Lillooet River (British Columbia, Canada) for discharge varying from $40 \mathrm{~m}^{3} / \mathrm{s}$ to $425 \mathrm{~m}^{3} / \mathrm{s}$. Flow velocity varied from 0.6 $\mathrm{m} / \mathrm{s}$ to $1.38 \mathrm{~m} / \mathrm{s}$ for dune field $A$ and from $0.60 \mathrm{~m} / \mathrm{s}$ to $1.56 \mathrm{~m} / \mathrm{s}$ for dune field $B$. The flow depth varied from $1.0 \mathrm{~m}$ to $4.6 \mathrm{~m}$ and from $1.0 \mathrm{~m}$ to $4.2 \mathrm{~m}$ for dune field $A$ and $B$, respectively. Average dune length observed during these investigations varied from $2 \mathrm{~m}$ to 21 $\mathrm{m}$ and from $2.4 \mathrm{~m}$ to $14.6 \mathrm{~m}$ for dune field $A$ and $B$, respectively. Average dune height observed during these investigations varied from $0.08 \mathrm{~m}$ to $0.96 \mathrm{~m}$ and from $0.09 \mathrm{~m}$ to $0.67 \mathrm{~m}$ for dune field $A$ and $B$, respectively. The dune steepness varied for from 0.02 to 0.10 and from 0.02 to 0.09 for dune field $A$ and $B$, respectively. The following figure (Figure 3 ) shows relationship between the flow depth and the dune length for available field data and empirical data from models analysed in this paper.

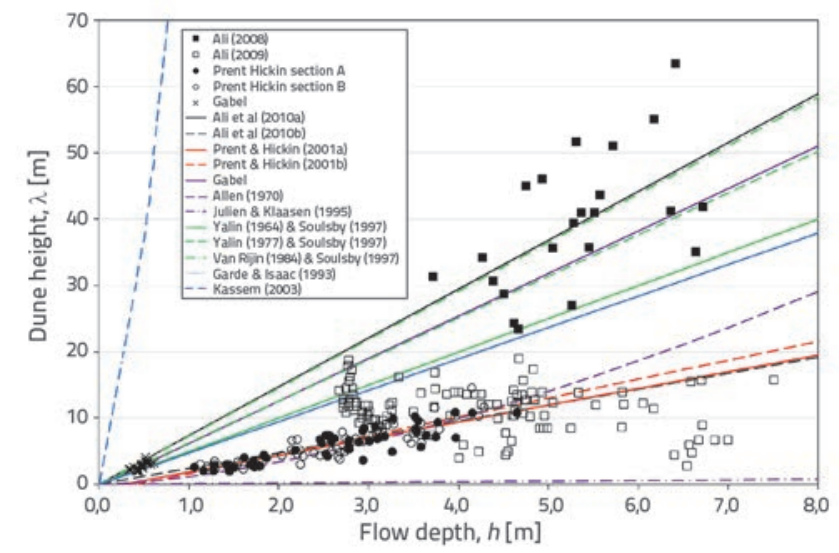

Figure 3. Relationship between flow depth and dune length; comparison of field data with empirical models

It can be seen that field data for dune lengths are grouped in four subsets:

1. Gable measurements comprising data from a small river characterised by small observed values and small dispersion of data 
2. Prent and Hickin measurements representing a homogeneous set for both dune fields on which data were collected

3. Ali et al. measurements from 2008 , characterized by largest dunes and considerable dispersion of data

4. Ali et al. measurements from 2009 that do not exhibit an obvious trend.

When analysing a trend from measured data, it can be concluded that Gabel's data and data by Ali et al. from 2008 follow a unique common trend. This trend is very well described by models given by Ali et al. and those by van Rijn, which also show the greatest increase in dune length with flow depth. Similar conclusion can be made for data presented by Ali et al. in 2009, and data by Prent and Hickin for both dune fields. Their trend is very well described by their models as well as Allen's model. It can be observed that field data is grouped close to the extremes of the dependant variable range covered by empirical models, both minimum and maximum. Models showing the minimum and maximum increase in dune length with flow depth are correlated with field data, while other models do not show correlation with them.

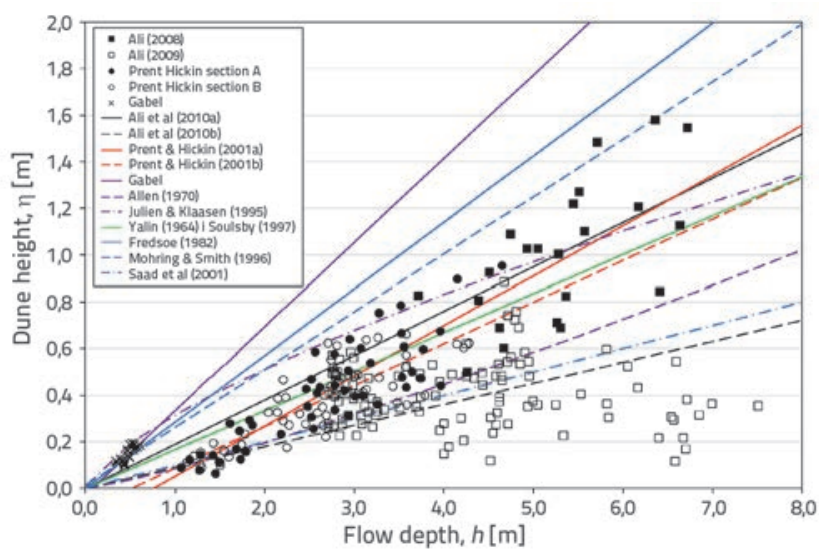

Figure 4. Relationship between flow depth and dune height; comparison of field data with empirical models

The following figure (Figure 4) shows relationship between the flow depth and the dune height for available field data and empirical data from models analysed in this paper. This figure reveals a much greater dissipation of data compared to dune length, which is primarily due to smaller range of values and less reliable measurement method. It can be seen that field dune height data are grouped into four subsets similar to those for the length. All models show, to a greater or lesser extent, correlation with measured data. Gabel, Fredsøe, and MohrigSmith models correlate exclusively with Gabel's data, while all others correlate with all other datasets. Gabel's data stands our separately from other field data, trending a great increase in dune height with the depth of flow, similar to the trend for dune lengths from the same dataset. Field data of Ali et al. form 2008 and the data of Prent and Hickin for both dune fields follow common relationship that can be explained fitting number of empirical models. The data presented by Ali et al. from 2009, much like for the length, do not exhibit an obvious trend and is situated outside of the range covered by empirical models.

A common feature of all analysed empirical models is that they predict continuous increase in dune dimensions with an increase in the flow depth, i.e. there is no factor that would limit this infinite growth of dunes. It can also be observed that most models are described using linear relationship because they are derived on a small dataset that does not contain the full range of variations that is present in natural rivers. The correlation between dune dimensions calculated by empirical models $X_{i z r}$ and available field data $X_{m j}$ is analysed using the coefficient of variation $V$ that represents the relative standardized measure of dispersion for interpretion of empirical model fit (Table 2). Coefficient of variation is defined as the ratio of the standard deviation to the arithmetic mean of dataset. For the analysed dune geometry data, the coefficient of variation is calculated as follows:

$V=\frac{\sigma}{\bar{x}} \cdot 100=\frac{\sqrt{\frac{\sum_{i=1}^{N}\left(x_{i z r}-x_{m j}\right)^{2}}{N}}}{\bar{x}} \cdot 100[\%]$

where:

$\sigma$ - standard deviation of a field dataset over empirical model data [m]

$\bar{X}$ - mean value for a field dataset [m]

$N$ - dataset size [-].

The analysis of deviation of dune dimensions calculated using empirical models from field data shows that there is a considerable difference between individual models, and that within particular model significant discrepancy in coefficient of variation exists between estimation of the dune length and height. Models presented by Neill, Jackson, Prent and IkedaIseya are special cases because laboratory conditions in which the methods are developed are limiting the application to flows under $0.5 \mathrm{~m}$ in depth, and provide negative values of dune length or height for the flow depths in excess of $0.5 \mathrm{~m}$. That is why coefficient of variation is considerably higher for these models compared to those that estimate positive increase in dune length with the flow depth. For dune length estimation using other models the coefficient of variation ranges from 81 $\%$ to $156 \%$, while the Kassem's model is an outlier (6566\%). For dune height estimation coefficient of variation ranges from $54 \%$ to $208 \%$, while the Allen method is an outlier ( $25879 \%$ ). These coefficients of variation are comparable to those used for sediment transport where ranges up to $200 \%$ are considered acceptable. The coefficient of variation for empirically calculated dune dimensions over measured values is presented in the following table. 
Table 2. Coefficient of variation for empirically calculated dune dimensions over measured values

\begin{tabular}{|c|c|c|}
\hline Model & $\boldsymbol{V}(\boldsymbol{\lambda})$ & $\boldsymbol{V}(\eta)$ \\
\hline Ali i dr. (2010a) & 156 & 78 \\
\hline Ali i dr. (2010b) & 83 & 58 \\
\hline Prent-Hickin (2001a) & 83 & 74 \\
\hline Prent-Hickin (2001b) & 81 & 62 \\
\hline Gabel (1993) & 128 & 208 \\
\hline Allen (1970) & 81 & 54 \\
\hline Julien-Klaasen (1995) & 134 & 86 \\
\hline Yalin (1964) & 95 & 65 \\
\hline Yalin (1977) & 126 & $/$ \\
\hline van Rijn (1984) & 155 & $/$ \\
\hline Garde-Isaac (1993) & 90 & $/$ \\
\hline Kassem (2003) & 6566 & 107 \\
\hline Fredsøe (1982) & $/$ & 151 \\
\hline Mohrig-Smith (1996) & $/$ & 123 \\
\hline Saad i dr. (2001) & $/$ & 55 \\
\hline Allen (1984) & $/$ & 25879 \\
\hline Neil (1969) & 348 & 598 \\
\hline Jackson (1976) & 393 & 85 \\
\hline Prent (1998) & 273 & 307 \\
\hline kkeda-Iseya (1980) & 224 & $/$ \\
\hline
\end{tabular}

If models containing equations for estimating both dune length and height are compared against one another, it can be seen that the smallest deviation is exhibited by the Allen model (1970), which gives the best fit to dune geometry. It is followed by models derived based on the presented field data, PrentHickin and Ali et al. (for the 2009 data). The research conducted by Ali et al. is important as hydrologic and hydraulic parameters of the Nile River reach in which dune field characteristics were investigated are very similar to those of the Drava River regarding riverbed material size, discharge, flow depth and velocity, and results can therefore be compared and applied in Croatian practice [43]. In their research, Ali et al. have fitted different empirical equations on their two datasets: field data from 2008 corresponds best with to the van Rijn model for dune length estimation, while for the dune height it corresponds best with to the Kassem model; field data from 2009 corresponds best to the Allen model for dune length estimation, while for the dune height it corresponds best to the Saad model. This variability between measured and calculated values is caused by limitations of empirical models used as they do not contain variables independent from the research site, which would otherwise permit their use across rivers with different flow characteristics.

Empirical relationships for prediction of dune geometry established on the flow depth as ingle predictor variable, neglecting underlying sedimentological processes, have been generally accepted because of their ease of application. In reality, direct generator of morphodynamic processes in riverbed is the bedload sediment transport and movement of sediment particles, i.e. the complex interaction between the turbulent flow, sediment transport, and dune properties. Bedload sediment transport as a direct generator of dunes can rarely be used to estimate dune properties as its direct on-site measurement is seldom possible. Instead, bedload sediment transport is often estimated using empirical models that do not reveal subtle morphodynamics underlying during migration. That is why complex interactions between turbulent flow, dune characteristics and sediment transport must be quantified so as to understand morphological development of riverbeds as a response to dune migration.

\section{Apparent bedload velocity}

The ADCP is an efficient and reliable instrument for the flow velocity measurement, whose advantages are best seen when it is necessary to conduct survey under highly unsteady flow conditions, a task too complex to undertake utilizing conventional methods. The most important advantages of ADCPs are the fast, adaptable methodology and three-dimensional velocity vector measurements. The ADCP measures flow velocity $v_{v, R E L}$ relative to its own absolute movement $\mathrm{v}_{\mathrm{B}}$. In order to calculate the absolute flow velocity $v_{v, A P S}$ its own absolute movement vector (i.e. of the boat onto which the instrument is mounted) $v_{B}$ must be deducted from the measured relative flow velocity vector $\mathrm{v}_{\mathrm{V}, \mathrm{REL}}$ :

$\overrightarrow{v_{V, A P S}}=\overrightarrow{v_{V, R E L}}-\overrightarrow{v_{B}}\left[\frac{m}{s}\right]$

The boat speed vector $\mathrm{v}_{\mathrm{B}}$ can be calculated from the Doppler shift of acoustic beam reflected from the riverbed, provided that the riverbed is immobile [44]. The boat speed vector calculated in this way can be prone to error if the riverbed is movable due to bedload sediment transport, which is often the case in sand-bed rivers. Fixed ADCP instrument that measures velocity field above the moving riverbed interprets the apparent bedload velocity $v_{V, A P S}$ as a fictitious upstream movement of the ADCP instrument. In this way, the sediment transport influences calculation of the absolute flow velocity $v_{v, A P S}$ by introducing bias that equals apparent bedload velocity vector (Figure 5). This introduction of bias into measurement of the absolute flow velocity vector in sand-bed rivers is a well-known phenomenon. Introduced bias can be eliminated by using the global positioning system (GPS) as a means to measure the absolute boat speed. The absolute boat speed is calculated from two successive GPS positions in form of vector that represents boat displacement in the interval $\Delta t$. By pairing the GPS with $A D C P$, the apparent bedload velocity can be calculated using the following expression: 
$\overrightarrow{v_{P D}}=\overrightarrow{v_{B, G G A}}-\overrightarrow{v_{B, \mathrm{BTM}}}\left[\frac{m}{s}\right]$

where:

$\overrightarrow{v_{P D}} \quad$ - apparent bedload velocity vector

$\overrightarrow{v_{B, G G A}}$ - actual boat displacement vector registered by GPS

$\overrightarrow{v_{B, \text { BTM }}}$ - vector of boat's speed-over-bottom registered by the ADCP's bottom-tracking feature [45-50].

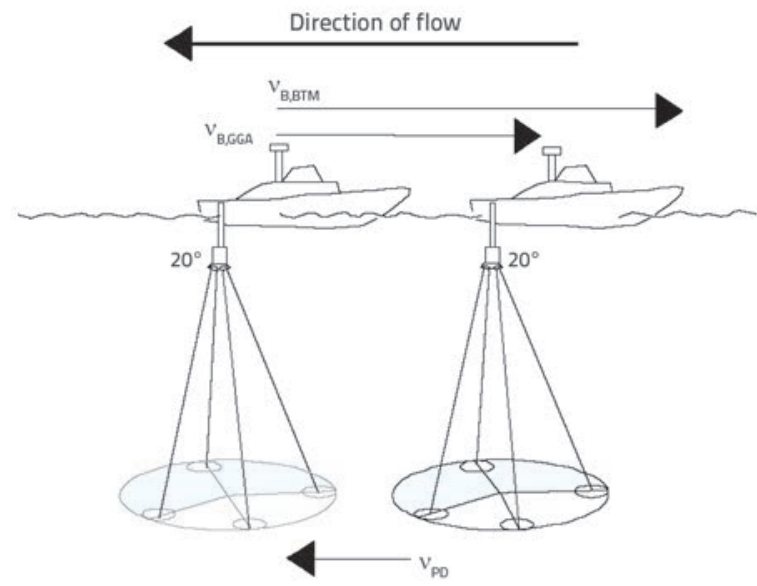

The correlation between $v_{p D}$ and $q_{b}$ (Figure 6.b) is stronger than the correlation between $\tau_{0}$ and $v_{P D}$ (Figure $6 \mathrm{a}$ ), which is quite expected as shear stress is a measure of the averaged flow characteristics, while the bedload transport also reflects the influence of the upstream sediment inflow, particle distribution within the riverbed and flow fluctuations. For that reason, shear stress is not strongly correlated even with the bedload transport. Rennie argued that mean bedload transport rate cannot be reliably predicted even with good estimation of the mean profile shear stress, but that it can be estimated from the measurement of the local apparent bedload velocity [52]. The easiest way to calculate the boat speed is to use the bottom-track method - a standard feature of the ADCP - so as to determine its movement above the riverbed. The boat speed vector $v_{B}$ measured using bottom-tracking method is more accurate than the measurement of the flow velocity vector [53]. The advantage of bottom tracking feature is that the measurements are conducted in the common coordinate system with the flow velocity vector measurements so that any compass error due to change in magnetic field does not influence the relative angle between the two measured vectors. The introduction of error in the measurements due to compass orientation becomes significant when it is used for conversion of data into the true north coordinate system so as to enable pairing with the GPS data [50]. The bottom-track feature
Figure 5. Schematic of bottom-tracking method and GPS for boat speed measurement used in coordination in river with movable riverbed, adapted from [49]

Using the ADCP, Rennie successfully measured the apparent bedload velocity and confirmed that for its reliable estimation from coordinated velocity measurement using bottom-tracking and GPS large measurement sample is needed. Rennie averaged the velocity field data in $5 \mathrm{~s}$ intervals and estimated that as many as 300 such intervals are needed for reliable assessment, which adds up to a 25-minute long survey. Based on the data gathered during his survey, he tested the strength of the relationship between the shear stress $\tau_{0}$ and apparent bedload velocity $v_{P D^{\prime}}$ as predictor variables and apparent bedload velocity $v_{P D}$ and unit bedload transport $q_{b}$ as dependent variables, respectively. Although individual data points show a considerable dissipation, the averaged values show a strong correlation for the relationship between $q_{b}$ and $v_{P D}$ [51]. The following figure shows correlation between the apparent bedload velocity, shear stress and bedload sediment transport from Rennie's analysis.
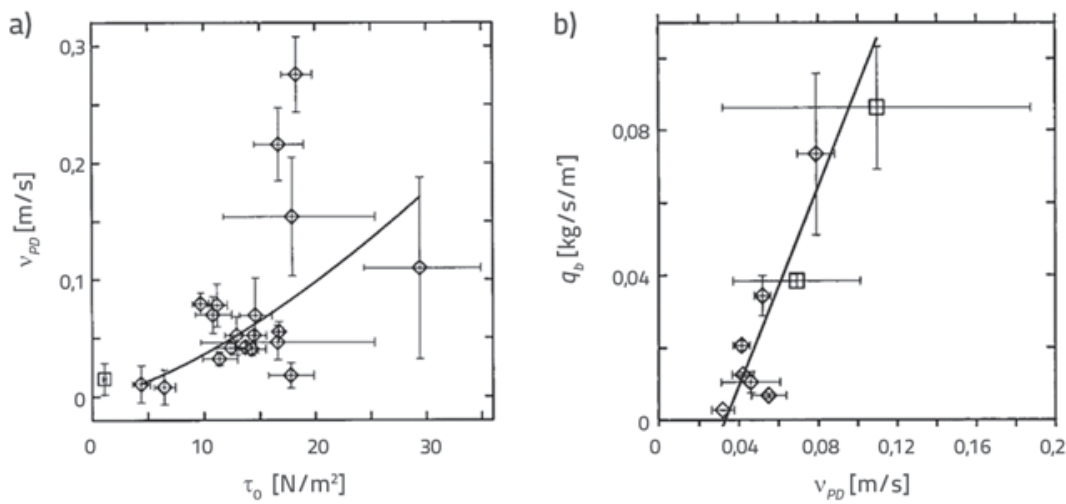

Figure 6. Relationship between: a) the shear stress and apparent bedload velocity; b) apparent bedload velocity and bedload sediment transport, adapted from [51]
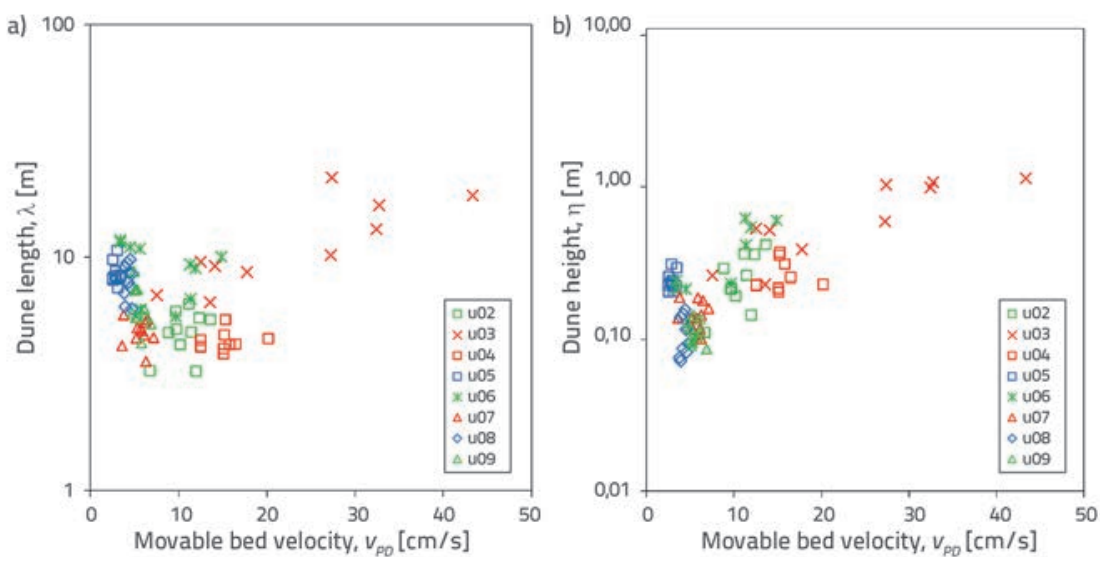

Figure 7. Relationship between: a) the dune length; b) dune height on the apparent bedload velocity for the Drava River 
also generates smaller short-term noises compared to the GPS, which results in more accurate data when measurement is made from a moving boat [53]. These ADCP characteristics enable rapid and efficient survey, adapted to hydrologic and hydraulic flow environment, but on the other hand, they can introduce system errors the extent of which has not as yet been clearly defined.

The analyses conducted in this paper show that the understanding of the sediment transport process, and its influence on flow resistance, could be improved by introducing apparent bedload velocity measurements in the standard hydrological monitoring. This additional variable would enable the shift of focus in the study of morphodynamic processes in natural rivers to process generators, rather than to the consequences. Apparent bedload velocity, as an independent predictor variable in empirical models for estimation of dune field characteristics, should result in a stronger correlation and more reliable relationship, compared to that based on the depth averaged flow parameters. The approach to the description of dune dynamics phenomena relying on apparent bedload velocity is as efficient and as reliable as the sediment transport measurement, based on modelling the flow using depth averaged values, and particle movement at the level of individual particles, by direct measurement of their movement, i.e. apparent bedload velocity. The study of dune dynamics conducted in the Drava River near Nemetin in the period from 2009 to 2014 [54] utilized ADCP to measure apparent bedload velocity using two methods:

- velocity profile measurements at repeatedly surveyed monitoring cross-sections for 6 minutes so as to obtain a representative sample

- measurement of dune field longitudinal profile along the main channel with simultaneous velocity profile measurements. The analysis of these measurements is given in Figure 7 .

The dependence of dune length and height on apparent bedload velocity is presented using averaged dune geometry and apparent bedload velocity for each monitoring cross-section (u02 - u09). The relationship between the dune geometry and apparent bedload velocity at the Drava River indicate that positive correlation in the interaction between the dune geometry and sediment transport exists. This partially differs from the empirical models presented in the literature review. The traditional approach based on empirical models using averaged flow parameters, such as the flow depth and velocity, as predictor variable cannot describe such unsteady dune field dynamics as their application is limited by conditions in which they are derived, which implies steady and uniform flow. In uniform flow, the intensity of all flow parameters usually increases with the discharge, which is an extremely rare occurrence in nature. The apparent bedload velocity, as a direct measure of bedload transport, has a potential for general use as an independent hydraulic variable. Apparent bedload velocity is a consequence of entrainment of sediment particles into the flow by near-bed turbulence, which makes it independent of profile averaged flow parameters. The dependence of the dune field geometry on the apparent bedload velocity must be studied under various hydrological and hydraulical conditions in natural rivers, so that the hypothesis on its general applicability can be confirmed on field surveys.

\section{Conclusion}

Although the importance of migrating dunes on river morphodynamics is well known in geomorphology, hydraulics and sedimentology, general theoretical approaches by which their dimensions and influence on the corresponding flow field could be quantified have not as yet been defined. Analyses of traditional empirical models for dune geometry estimation have quantified their unreliability in relation to dunes measured in nature, where it has been demonstrated that the discrepancy between them can exceed real dune dimensions by several times. The simplification of physical processes used in such methods makes them unusable under conditions that do not coincide with those under which these methods were derived. The authors suggest that the interaction of dunes with instantaneous flow field is described using the apparent bedload velocity that can indirectly be calculated from simultaneous measurements of the flow velocity profile and absolute movement of the instrument. Apparent bedload velocity approach is based on the sediment transport theory at the level of individual particles where near-bed turbulence entrains sediment particles into the flow, and is as efficient and reliable as traditional methods. Therefore, apparent bedload velocity, as a direct measure of bedload transport, has a potential for general use as an independent hydraulic variable, but its applicability has to be additionally explored under various hydrological and hydraulical conditions in natural rivers.

\section{REFERENCES}

[1] Mazumder, R.: Sediment transport, aqueous bedform stability and morphodynamics under unidirectional current:a brief overview Journal of African Earth Sciences, 36 (2003), pp. 1-14, https://doi. org/10.1016/S0899-5362(03)00018-6

[2] McLean, S.R.: The stability of ripples and dunes, Earth-Science Reviews, 29 (1990) 1-4, pp. 131-144, https://doi.org/10.1016/00128252(0)90022-N

[3] Omidyeganeh, M., Piomelli, U.: Large eddies in the flow over dunes, Seventh International Symposium on Turbulence and Shear Flow Phenomena (TSFP7), Ottawa, Canada, University of Ottawa, July 28 31, 2011.

[4] Best, J.: The fluid dynamics of river dunes: A review and some future research directions, Journal of Geophysical Research, 110 (2005), pp. F04S02, PP 21

[5] Dinehart, R.L.: Bedform movement recorded by sequential singlebeam surveys in tidal rivers, Journal of Hydrology, 258 (2002), pp. 25 39, https://doi.org/10.1016/S0022-1694(01)00558-3.
[6] Motamedi, A., Afzalimehr, H., Gallichand, J., Abadi, E.F.N.: Lee Angle Effects in Near Bed Turbulence: An Experimental Study on Low and Sharp Angle Dunes, International Journal of Hydraulic Engineering, 1 (2012) 6, pp. 68-74.

[7] Allen, J.R.L.: Sedimentary Structures - Their Character and Physical Basis Volume I, Developments in Sedimentology, 30A (1982), pp. 593.

[8] Ashley, G.M.: Classification of large-scale subaqueous bedforms: a new look at an old problem, Journal of Sedimentary Research, 60 (1990) 1, pp. 160-172.

[9] Venditti, J.G., Bennett, S.J.: Spectral analysis of turbulent flow and suspended sediment transport over fixed dunes, Journal of Geophysical Research, 105 (2000) C9, pp. 22035-22047.

[10] Rauen, W.B., Lin, B., Falconer, R.A.: Modelling ripple development under non-uniform flow and sediment supply-limited conditions in a laboratory flume, Estuarine, Coastal and Shelf Science, 82 (2009), pp. 452-460, https://doi.org/10.1016/j.ecss.2009.02.015

[11] Chanson, H.: The Hydraulics of Open Channel Flow: An Introduction, Elsevier Butterworth-Heinemann, Oxford, Great Britain, 2004. 
[12] Henning, M., Aberle, J., Coleman, S.E.: Analysis of 3D-bed form migration rates, River Flow, Braunschweig, Germany, Bundesanstalt für Wasserbau, pp. 879-885, 2010

[13] Clunie, T.M.: Flow Over Fluvial Bedforms, Auckland, The University of Auckland, pp. Pages, 2012.

[14] Coleman, S.: Experimental Investigations of Sandy Riverbed Morphology, Experimental Methods in Hydraulic Research, eds. P Rowinski, Springer-Verlag Berlin Heidelberg, Berlin, pp. 1-27, 2011 https://doi.org/10.1007/978-3-642-17475-9_1

[15] Paarlberg, A.J., Dohmen-Janssen C. M., Hulscher S. J. M. H., Termes P.: A parameterization of flow separation over subaqueous dunes, Water Resources Research, 43 (2007), pp. W12417, 10 PP.

[16] Holmes, R.R., Garcia, M.H.: Flow over bedforms in a large sand-bed river: A field investigation, Journal of Hydraulic Research, 46 (2008) 3 pp. 322-333.

[17] Chen, J., Wang, Z., Li, M., Wei, T., Chen, Z.: Bedform characteristics during falling flood stage and morphodynamic interpretation of the middle-lower Changjiang (Yangtze) River channel, China Geomorphology, 147-148(2012), pp. 18-26, https://doi.org/10.1016/j. geomorph.2011.06.042

[18] van Rijn, L.C.: Sediment Transport, Part III: Bed Forms and Alluvial Roughness, Journal of Hydraulic Engineering, 110 (1984) 12, pp. 1733-1754.

[19] Venditti, J.G., Church, M.A., Bennett, S.J.: Morphodynamics of small-scale superimposed sand waves over migrating dune bed forms, Water Resources Research, 41 (2005), https://doi org/10.1029/2004wr003461

[20] Fredsøe, J.: Shape and Dimensions of Stationary Dunes in Rivers, Journal of the Hydraulics Division, 108 (1982) 8, pp. 932-947.

[21] Kostaschuk, R., Villard, P.: Flow and sediment transport over large subaqueous dunes: Fraser River, Canada, Sedimentology, 43 (1996) pp. 849-863, https://doi.org/10.1111/j.1365-3091.1996.tb01506.x

[22] Lin, C.-Y.M.: Bedform migration in rivers, Burnaby, Simon Fraser University, Master Thesis, 2011.

[23] van den Berg, J.H.: Bedform migration and bed- load transport in some rivers and tidal environments, Sedimentology, 34 (1987), pp. 681 698, https://doi.org/10.1111/j.1365-3091.1987.tb00794.x

[24] Simons, D.B., Richardson, E.V., Nordin, C.F.: Bedload equation for ripples and dunes, U.S. Geological Survey Paper 462-H, Washington D. C., 1965.

[25] Prent, M.T.H., Hickin, E.J.: Annual regime of bedforms, roughness and flow resistance, Lillooet River, British Columbia, BC, Geomorphology 41 (2001), pp. 369-390, https://doi.org/10.1016/S0169555X(01)00068-X

[26] Ali, M., Attia, K., El Bahrawy, A.: Bed Form Types and Dimensions at El Ekhsas Gauge Station From Field Measurements, Nile Basin Water Science \& Engineering Journal, 3 (2010) 3, pp. 14-25.

[27] van Rijn, L.C.: Sediment Transport, Part I: Bed Load Transport, Journa of Hydraulic Engineering, 110 (1984) 10, pp. 1431-1456.

[28] Shields, A.F.: Anwendung der Aehnlichkeitsmechanik und der Turbulenzforschung auf die Geschiebebewegung, Berlin, Technical University Berlin, 1936.

[29] Jackson, R.G.: Sedimentological and fluid-dynamic implications of the turbulent bursting phenomenon in geophysical flows, Journal of Fluid Mechanics, 77 (1976), pp. 531-560, https://doi.org/10.1017/ S0022112076002243

[30] Gabel, S.L.: Geometry and kinematics of dunes during steady and unsteady flows in the Calamus River, Nebraska, USA, Sedimentology, 40 (1993) 2, pp. 237-269.

[31] Babakaiff, S.C.: Flow Hydraulics, Bedforms And Macroturbulence Of Squamish River Estuary, British Columbia, Simon Fraser University, 1993.

[32] Stow, D.A.V., Hernández-Molina, J., Llave, E., Sayago-Gil, M., Río, V.D., Branson, A.: Bedform-velocity matrix: The estimation of bottom current velocity from bedform observations, Geology, 37 (2009) 4, pp. 327-330

[33] Giri, S., Shimizu, Y.: Numerical computation of sand dune migration with free surface flow, Water Resources Research, 42 (2006) 10, https://doi.org/10.1029/2005WR004588
[34] Nelson, J.M., Shreve, R.L., McLean, S.R., Drake, T.G.: Role of Near-Bed Turbulence Structure in Bed Load Transport and Bed Form Mechanics, Water Resources Research, 31 (2010) 8, pp. 2071-2086.

[35] Lončar, G., Carević, D., Bekić, D., Babić, M., Grbić, N., Pranjić, V.: Analiza morfodinamičke stabilnosti poprečnog profila šljunčane plaže, GRAĐEVINAR, 68 (2016) 2, pp. 113-124, https://doi.org/10.14256/ JCE.1472.2015

[36] Kostaschuk, R.: A field study of turbulence and sediment dynamics over subaqueous dunes with flow separation, Sedimentology, 47 (2000), pp. 519-531, https://doi.org/10.1046/j.1365-3091.2000.00303.x

[37] Termini, D., Sammartano, V.: Experimental Analysis of Relations Between Coherent Turbulent Structures and Formation of Bedforms, Archives of Hydro-Engineering and Environmental Mechanics, 55 (2008) 3-4, pp. 125-143.

[38] Diplas, P., Dancey, C.L., Celik, A.O., Valyrakis, M., Greer, K., Akar, T.: The Role of Impulse on the Initiation of Particle Movement Under Turbulent Flow Conditions, Science, 322 (2008) 5902, pp. 717-720.

[39] Carling, P.A., Gölz, E., Orr, H.G., Radecki-Pawlik, A.: The morphodynamics of fluvial sand dunes in the River Rhine, near Mainz, Germany. I. Sedimentology and morphology, Sedimentology, 47 (2000), pp. 227-252, https://doi. org/10.1046/j.1365-3091.2000.00290.x

[40] Garde, R.J.: River Morphology, New Age International (P) Ltd., Publishers, New Delhi, 2006.

[41] Garcia, M.H.: Sedimentation Engineering: Processes, Measurements, Modeling, and Practice, M. H. Garcia, editor, American Society of Civil Engineers, Reston, Virginia, 2008, https://doi. org/10.1061/9780784408148

[42] Yalin, M.S.: Mechanics of Sediment Transport, Elsevier, New York, 1977.

[43] Gilja, G., Bekić, D., Oskoruš, D.: Processing of Suspended Sediment Concentration Measurements on Drava River, Proceedings of International Symposium on Water Management and Hydraulic Engineering, Ohrid, Republic of Macedonia, pp. 181-191, 2009

[44] Simpson, M.R.: Discharge Measurements Using a Broad-Band Acoustic Doppler Current Profiler, U.S. Geological Survey, Sacramento, California, 2001

[45] Mueller, D.S., Wagner, C.R.: Measuring discharge with acoustic Doppler current profilers from a moving boat, U.S. Geological Survey Techniques and Methods 3A-22USGS, Reston, Virginia, pp. 72, 2009.

[46] Rennie, C.D., Rainville, F., Kashyap, S.: Improved Estimation of ADCP Apparent Bed-Load Velocity Using a Real-Time Kalman Filter, Journal of Hydraulic Engineering, 133 (2007) 12, pp. 1337-1344.

[47] Rennie, C.D., Rainville, F.: Case Study of Precision of GPS Differential Correction Strategies: Influence on aDcp Velocity and Discharge Estimates, Journal of Hydraulic Engineering, 132 (2006) 3, pp. 225234

[48] Wagner, C.R., Mueller, D.S.: Comparison of bottom-track to global positioning system referenced discharges measured using an acoustic Doppler current profiler, Journal of Hydrology, 401 (2011), pp. 250258, https://doi.org/10.1016/j.jhydrol.2011.02.025

[49] Villard, P.V., Church, M.A., Kostaschuk R. Estimating bed load in sand-bed channels using bottom tracking from an acoustic Doppler profiler. In: M. D. In: Blum, Marriott, S. B. (Eds.), Fluvial sedimentology VII, editor. Kingston-upon-Thames, UK: International Association of Sedimentologists, Blackwell, pp. 197-209, 2005

[50] Gilja, G., Bekić, D., Kuspilić, N.: Comparison of flow velocity vectors collected by using RTK-GPS and bottom-tracking as a reference on a boat mounted ADCP, Current events in hydraulic engineering, eds. J. M. Sawicki \& P. Zima, Gdansk University of Technology, Gdansk, pp. 123135, 2011.

[51] Rennie, C.D., Millar, R.G., Church, M.A.: Measurement of Bed Load Velocity using an Acoustic Doppler Current Profiler, Journal of Hydraulic Engineering, 128 (2002) 5, pp. 473-783.

[52] Rennie, C.D., Millar, R.G.: Measurement of the spatial distribution of fluvial bedload transport velocity in both sand and gravel, Earth Surface Processes and Landforms, 29 (2004), pp. 1173-1193, https:// doi.org/10.1002/esp.1074

[53] Gordon, R.L.: Acoustic Doppler Current Profiler: Principles of Operation - A Practical Primer, RD Instruments, San Diego, California, 1996.

[54] Gilja, G.: Utjecaj brzine pokretnog dna na migraciju 2D superponiranih dina [Doktorska disertacija], Zagreb, Sveučilište u Zagrebu Građevinski fakultet, 2014 